\title{
NO DIRECT EFFECTS OF RESISTANT SOYBEAN CULTIVAR IAC-24 ON Podisus nigrispinus (HETEROPTERA: PENTATOMIDAE)
}

\author{
José Cola Zanuncio $^{1 *}$, Fernando Azevedo de Freitas ${ }^{2}$, Wagner de Souza Tavares ${ }^{2}$, \\ André Luiz Lourenção ${ }^{3}$, Teresinha Vinha Zanuncio ${ }^{1}$, and José Eduardo Serrão ${ }^{4}$
}

\begin{abstract}
The parameters of survival, development and reproduction of Podisus nigrispinus Dallas, 1851 (Heteroptera: Pentatomidae) may be affected by feeding on soybean (Glycine max [L.] Merr.; Fabaceae) cultivars. The direct effect was evaluated of the insect-resistant soybean 'IAC-24' (insect-susceptible soybean 'UFVS-2006' + pupae of Tenebrio molitor L., 1758 [Coleoptera: Tenebrionidae] versus 'IAC-24' plants + pupae of T. molitor) in the nymph and adult stages of the predator $P$. nigrispinus. The duration of the nymph stage was similar between treatments, but 'IAC-24' reduced the duration of the IV instar of this predator. The survival of $P$. nigrispinus was similar between treatments in the instars I, II, IV and V and in the nymph stage, but the survival of the III instar was longer with 'IAC-24' plants. The body mass of nymphs in the first day of the III, IV, and V instars after ecdysis and newly emerged adults; reproductive characteristics (periods of pre-oviposition, oviposition, post-oviposition and egg incubation; egg laying interval, number of egg masses per female, nymphs per female, nymphs per egg mass and percentage of nymphs hatching) and life span of males and females of $P$. nigrispinus were similar between treatments. The resistant soybean 'IAC-24' showed no direct deleterious effects on P. nigrispinus, which implies its innocuity and compatibility with this predator.
\end{abstract}

Key words: Asopinae, biological control, integrated pest management, predator, soybean.

$P$ odisus nigrispinus Dallas, 1851 (Heteroptera: Pentatomidae) is an important predator for the control of defoliating caterpillars in soybean crops, Glycine max (L.) Merr. (Fabaceae), such as Anticarsia gemmatalis Hübner, 1818 (Lepidoptera: Noctuidae) (Saavedra et al., 1997; Ferreira et al., 2008). This natural enemy may also feed on soybean plants, although some of its biological parameters are affected in resistant cultivars (Matos Neto et al., 2002). Podisus nigrispinus and other predators of this group are reared in the laboratory with an alternative prey, pupae of Tenebrio molitor L., 1758 (Coleoptera: Tenebrionidae), and released into the field in soybean crops for the pest control (Neves et al., 2010).

The soybean 'IAC-24' was obtained from the cross between 'IAC 80-1177' and 'IAC 83-288' by researchers at the 'Instituto Agronômico de Campinas (IAC)' in Campinas, São Paulo State, Brazil. This cultivar is suitable for cultivation in São Paulo and Minas Gerais States, Brazil, and in areas with similar soil and climatic

${ }^{1}$ Universidade Federal de Viçosa, Departamento de Biologia Animal, Viçosa 36570-000, Minas Gerais, Brasil.

${ }^{2}$ Universidade Federal de Viçosa, Departamento de Fitotecnia, Viçosa 36570-000, Minas Gerais, Brasil.

*Corresponding author (zanuncio@ufv.br).

${ }^{3}$ Instituto Agronômico de Campinas, Avenida Barão de Itapura, nº1481, Jardim Botafogo, Campinas 13020-902, São Paulo, Brasil.

${ }^{4}$ Universidade Federal de Viçosa, Departamento de Biologia Geral, Viçosa 36570-000, Minas Gerais, Brasil.

Received: 24 July 2012.

Accepted: 9 September 2012. conditions, with resistance to lepidopteran pests and Euschistus heros F., 1798; Edessa meditabunda F., 1794 and Nezara viridula L., 1758 (Hemiptera: Pentatomidae) and with high productivity (Miranda et al., 2003). However, the effects of the soybean 'IAC-24' on biological parameters of $P$. nigrispinus are unknown. The resistance of plants and biological control can be combined in integrated pest management (IPM) programs of soybean crops (Bartlett, 2008; Piubelli et al., 2009; Tavares et al., 2011).

The compatibility of plant resistance and biological control is due to ingestion of deleterious substances from resistant plants by the pests, without effects on zoophytophagous predators and selectivity to other predators and parasitoids (Matos Neto et al., 2002; Tavares et al., 2009). Predatory insects can be affected by deleterious substances when feeding on resistant plants or phytophagous insects reared with these plants (Rogers and Sullivan, 1986; Pfannenstiel and Yeargan, 1998). The predators Cyrtorhinus lividipennis Reuter, 1885 (Hemiptera: Miridae) and Microvelia douglasi atrolineata Bergroth, 1918 (Hemiptera: Veleiidae) reduced the population of Nilaparvata lugens Stål, 1854 (Hemiptera: Delphacidae) on susceptible plants of Oryza sp. (Poaceae) more than on resistant plants (Kartohardjono and Heinrichs, 1984). The life span of adults can be shorter and fecundity and predation lower in resistant plants. The insect-resistant soybean PI227687 increased the oviposition period of the predator Podisus 
maculiventris Say, 1832 (Heteroptera: Pentatomidae) (Orr and Boethel, 1986). Plants can reduce the nymph period and increase weight, fecundity and longevity of adult predators (Zanuncio et al., 2000).

The objective of this study was to evaluate duration, survival, body mass, reproductive characteristics and life span of nymphs and adults of $P$. nigrispinus feeding on pupae of T. molitor on plants of insect-resistant soybean 'IAC-24', compared to the insect-susceptible soybean 'UFVS-2006'.

\section{MATERIALS AND METHODS}

Seeds of the insect-susceptible soybean 'UFVS-2006' were obtained from the Universidade Federal de Viçosa (UFV) in Viçosa, Minas Gerais, Brazil, and the insect-resistant 'IAC-24' from the Instituto Agronômico de Campinas (IAC) in Campinas, São Paulo, Brazil. These cultivars were sown in vases of $5 \mathrm{~L}$ capacity in an experimental area of the Insectarium of the Departamento de Biologia Animal (DBA) of the UFV. The soil was fertilized according to the guidelines of the Soil Fertility Commission of the State of Minas Gerais and the plants used were in the stages V6 or V7 (vegetative) until stage R6 (reproductive). These stages of soybeans are the most commonly attacked by pests in the field (Corrêa-Ferreira, 2005).

The pupae of $T$. molitor were obtained from a rearing facility of this prey fed with wheat bran and brewer yeast from the Laboratório de Controle Biológico de Insetos (LCBI) (DBA-UFV). Egg masses were obtained from the mass rearing of $P$. nigrispinus from the LCBI where this insect was fed with T. molitor pupae. The eggs were sorted in Petri dishes ( $9 \mathrm{~cm}$ diameter x $1.2 \mathrm{~cm}$ height) with moistened cotton pads to avoid desiccation. The first and second instar of $P$. nigrispinus received soybean folioles from cultivars 'UFVS-2006' or 'IAC-24' and T. molitor pupae in Petri dishes. After the third instar, the predators were placed in organza bags with 10 pupae of T. molitor and replaced as necessary and submitted to the field experiment. Pupae of T. molitor were used because this insect is an alternative prey to predators in the laboratory (Neves et al., 2010).

\section{Experiment and parameters evaluated}

The direct action of the insect-resistant 'IAC-24' on characteristics such as survival, body mass, reproduction, and longevity of P. nigrispinus was analyzed with pupae of the alternative prey $T$. molitor. This field assay was performed with individuals of $P$. nigrispinus and pupae of $T$. molitor in white organza bags $(30 \mathrm{~cm}$ length $\times 20$ $\mathrm{cm}$ diameter) containing a soybean branch per unit in the treatments: T1- P. nigrispinus, pupae of T. molitor and one branch of the 'UFVS-2006' (non-resistant) and T2- $P$. nigrispinus, pupae of T. molitor and one branch of the 'IAC24' (resistant), with 11 replicates, each inside an organza bag with a couple of $P$. nigrispinus. Prey were supplied ad libitum and replaced when necessary. Vases of soybean plants were placed in the field and covered with organza.

We evaluated and analyzed biological parameters such as duration and survival of the I, II, III, IV, and V instars; total nymph stage, body mass of nymphs at the first day of I, IV, and V instars and newly emerged males and females; pre-oviposition, oviposition, and post-oviposition periods and egg incubation; interval between egg-laying; number of egg masses per female, of eggs per egg mass, of eggs per female, nymphs per female, nymphs per egg mass, percentage of nymph hatching and life span of males and females of $P$. nigrispinus. The body mass of this predator was determined with a Coleman FA1604 scale with precision of $0.1 \mathrm{mg}$.

The parameters were measured daily from 08:00 am to 12:00 pm. Organza bags were opened to record data in a datasheet attached to a clipboard. The climatic conditions of the cultivation site were evaluated (Table 1).

\section{Statistical analysis}

The experimental design was completely randomized and the data submitted to ANOVA with the means compared by the student's t-test at $5 \%$ probability. The data of nymph survival and body mass were submitted to a non-parametric ANOVA by the Wilcoxon test at $5 \%$ probability because they did not present the presuppositions of variance homogeneity and normal distribution. Analyses were processed using SAS (SAS Institute, 1989) (Supplier: UFV).

Table 1. Monthly mean, maximum, and minimum temperature, relative humidity; mean daily rainfall and photoperiod per month. Municipality of Viçosa, Minas Gerais, Brazil. March to November 2010.

\begin{tabular}{|c|c|c|c|c|c|c|}
\hline Months & $\begin{array}{c}\text { Mean } \\
\text { temperature }\end{array}$ & $\begin{array}{l}\text { Maximum } \\
\text { temperature }\end{array}$ & $\begin{array}{l}\text { Minimum } \\
\text { temperature }\end{array}$ & $\begin{array}{l}\text { Relative } \\
\text { humidity }\end{array}$ & Rainfall & Photoperiod \\
\hline & & ${ }^{\circ} \mathrm{C}-$ & - & $\%$ & $\mathrm{~mm}$ & $\mathrm{~h} \mathrm{~d}^{-1}$ \\
\hline March & 23.00 & 30.00 & 19.06 & 80.79 & 1.06 & 11.88 \\
\hline April & 21.86 & 29.86 & 16.95 & 77.65 & 1.12 & 11.52 \\
\hline May & 19.12 & 26.31 & 14.69 & 78.96 & 1.91 & 11.02 \\
\hline June & 17.92 & 25.61 & 13.30 & 80.71 & 0.01 & 10.76 \\
\hline July & 16.84 & 25.00 & 11.70 & 77.91 & 0.06 & 10.87 \\
\hline August & 18.33 & 26.53 & 12.41 & 74.81 & 0.21 & 11.03 \\
\hline September & 19.07 & 25.87 & 14.28 & 74.05 & 2.67 & 11.89 \\
\hline October & 20.49 & 26.72 & 16.19 & 74.29 & 4.91 & 12.49 \\
\hline November & 22.18 & 27.70 & 18.68 & 81.73 & 7.71 & 13.00 \\
\hline Mean & 19.55 & 26.77 & 14.86 & 77.58 & 2.29 & 11.61 \\
\hline
\end{tabular}




\section{RESULTS}

The duration in days of the I, II, III, and V instars and of the nymph stage of $P$. nigrispinus did not differ between treatments $(p>0.05)$, but the duration of the IV instar was shorter on insect-resistant 'IAC-24'plants $(p<0.05)$. The survival of $P$. nigrispinus did not differ between treatments in the I, II, IV, and V instars and the nymph stage $(p>0.05)$. However, the survival rate of the III instar was higher with plants 'IAC-24' plants $(p<0.05)$ (Table 2).

The body masses of individual male and female nymphs of P. nigrispinus were similar between treatments $(p>0.05)$ (Table 3).

Periods of pre-oviposition $(t=0.23, g l=20$ and $p>$ $0.05)$, oviposition $(t=0.24, g l=20$ and $p>0.05)$ and post-oviposition $(t=1.49, g l=10.4$ and $p>0.05)$ of $P$. nigrispinus females did not differ between treatments (Table 4).

The interval between egg mass laying $(t=1.29, g l=$ 20 and $p>0.05)$, egg incubation period $(t=0.49, g l=20$ and $p>0.05)$; number of egg masses per female $(t=0.50$, $g l=20$ and $p>0.05)$, eggs per female $(t=0.08, g l=20$ and $p>0.05)$, eggs per egg mass $(t=1.30, g l=20$ and $p>0.05)$; percentage of nymph hatching $(t=0.02, g l=$

Table 2. Duration and survival (mean \pm standard error of the mean) of instars I, II, III, IV, V, and nymph stage of Podisus nigrispinus (Heteroptera: Pentatomidae) fed with pupae of Tenebrio molitor (Coleoptera: Tenebrionidae) on plants of the insect-susceptible soybean 'UFVS-2006' (T1) or insect-resistant 'IAC-24' (T2).

\begin{tabular}{lcc}
\hline & \multicolumn{2}{c}{ Duration (d) } \\
\cline { 2 - 3 } Stages & T1 ('UFVS-2006') & T2 ('IAC-24') \\
\hline $\mathrm{I}^{\mathrm{ns}}$ & $2.75 \pm 0.19$ & $2.63 \pm 0.17$ \\
$\mathrm{II}^{\mathrm{ns}}$ & $4.12 \pm 0.18$ & $4.13 \pm 0.17$ \\
$\mathrm{III}^{\mathrm{ns}}$ & $4.12 \pm 0.20$ & $4.38 \pm 0.33$ \\
IV $^{*}$ & $5.32 \pm 0.19 \mathrm{~A}$ & $4.76 \pm 0.16 \mathrm{~B}$ \\
$\mathrm{~V}^{\mathrm{ns}}$ & $6.73 \pm 0.15$ & $6.65 \pm 0.08$ \\
Nymphal stage $^{\mathrm{ns}}$ & $23.04 \pm 0.44$ & $22.55 \pm 0.50$ \\
& & Survival $(\%)^{\mathrm{ns}}$ \\
$\mathrm{I}^{\mathrm{ns}}$ & $98.18 \pm 1.22$ & $98.18 \pm 1.22$ \\
$\mathrm{II}^{\mathrm{ns}}$ & $98.08 \pm 1.29$ & $95.45 \pm 3.66$ \\
III $^{* *}$ & $88.28 \pm 3.51 \mathrm{~B}$ & $97.40 \pm 2.60 \mathrm{~A}$ \\
IV $^{\mathrm{ns}}$ & $97.69 \pm 1.56$ & $97.27 \pm 2.73$ \\
$\mathrm{~V}^{\text {ns }}$ & $100.00 \pm 0.00$ & $97.56 \pm 1.64$ \\
Nymphal stage $^{\mathrm{ns}}$ & $82.45 \pm 3.50$ & $85.86 \pm 5.36$ \\
\hline
\end{tabular}

Means followed by the same capital letter per line do not differ according to the $\mathrm{F}$ test.

${ }^{\mathrm{n}} \mathrm{N}$ Non-significant at $5 \%$ according to the $\mathrm{F}$ test.

"Significant at $5 \%$ according to the $\mathrm{F}$ test.

${ }^{*}$ Significant at $1 \%$ according to the Wilcoxon test.

Table 3. Body mass of nymphs (mean \pm standard error of the mean) in the first day of III, IV, and V instars after ecdysis and newly-emerged adults of Podisus nigrispinus (Heteroptera: Pentatomidae) fed with pupae of Tenebrio molitor (Coleoptera: Tenebrionidae) on plants of the insectsusceptible soybean 'UFVS-2006' (T1) or insect-resistant 'IAC-24' (T2).

\begin{tabular}{lcr}
\hline & \multicolumn{2}{c}{ Body mass $(\mathrm{mg})$} \\
\cline { 2 - 3 } $\mathrm{III}^{\mathrm{ns}}$ & $\mathrm{T} 1$ ('UFVS-2006') & T2 ('IAC-24') \\
$\mathrm{IV}^{\mathrm{ns}}$ & $3.71 \pm 0.28$ & $3.92 \pm 0.34$ \\
$\mathrm{~V}^{\text {ns }}$ & $10.13 \pm 0.43$ & $10.94 \pm 0.53$ \\
Male $^{\text {ns }}$ & $27.02 \pm 1.14$ & $26.71 \pm 1.46$ \\
Female $^{\text {ns }}$ & $44.17 \pm 0.86$ & $44.66 \pm 0.52$ \\
\hline
\end{tabular}

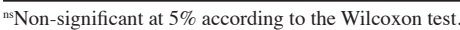

Table 4. Reproductive characteristics (mean \pm standard error of the mean) of Podisus nigrispinus (Heteroptera: Pentatomidae) fed with pupae of Tenebrio molitor (Coleoptera: Tenebrionidae) on plants of the insectsusceptible soybean 'UFVS-2006' (T1) or insect-resistant 'IAC-24' (T2).

\begin{tabular}{lccc}
\hline $\begin{array}{l}\text { Characteristics } \\
\text { evaluated }\end{array}$ & T1 ('UFVS-2006') & T2 ('IAC-24') & Prob.' \\
\hline Pre-oviposition periods, d & $7.09 \pm 0.31$ & $7.18 \pm 0.23$ & 0.41 \\
Oviposition periods, d & $25.45 \pm 3.91$ & $24.09 \pm 4.10$ & 0.41 \\
Post-oviposition periods, d & $0.18 \pm 0.12$ & $1.45 \pm 0.85$ & 0.08 \\
Interval between egg-laying, d & $2.27 \pm 0.15$ & $1.99 \pm 0.15$ & 0.11 \\
Egg incubation periods, d & $4.75 \pm 0.04$ & $4.71 \pm 0.06$ & 0.32 \\
Number of egg masses per female & $11.73 \pm 1.57$ & $13.18 \pm 2.42$ & 0.31 \\
Number of eggs per female & $336.64 \pm 46.81$ & $342.73 \pm 57.42$ & 0.47 \\
Number of eggs per laying & $28.69 \pm 1.30$ & $26.45 \pm 1.14$ & 0.10 \\
Nymph hatching, \% & $89.36 \pm 2.54$ & $89.29 \pm 2.07$ & 0.49 \\
Number of nymphs per female & $298.27 \pm 41.27$ & $304.55 \pm 52.51$ & 0.46 \\
\hline 'Student's t-test. & & &
\end{tabular}

20 and $p>0.05)$ and number of nymphs per female of $P$. nigrispinus $(t=0.09, g l=20$ and $p>0.05)$ were similar between treatments (Table 4$)$.

The life spans of males $(t=1.64, g l=20$ and $p>$ $0.05)$ and females $(t=0.00, g l=20$ and $p>0.05)$ of $P$. nigrispinus were similar between treatments (Figure 1).

The mortality rates of $P$. nigrispinus females were similar between treatments and with higher values between days 35 and 45 on the insect-resistant soybean 'IAC-24' (Figure 2).

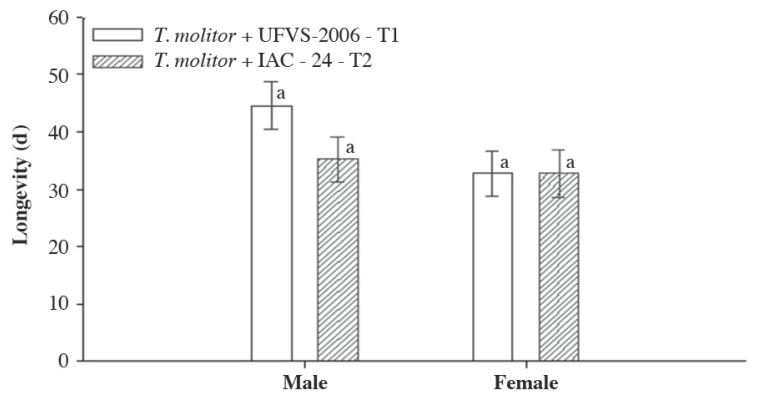

Columns followed by the same letter do not differ according to Student's t-test $(p>0.05)$.

Figure 1. Life span (mean \pm standard error of the mean) of males and females Podisus nigrispinus (Heteroptera: Pentatomidae) fed with Tenebrio molitor (Coleoptera: Tenebrionidae) pupae on plants of the insect-susceptable soybean 'UFVS-2006' (T1) or insect-resistant 'IAC-24' (T2).

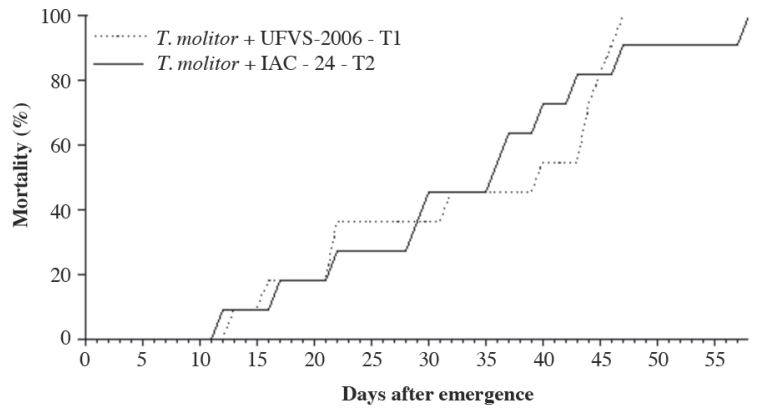

Figure 2. Mortality of Podisus nigrispinus (Heteroptera: Pentatomidae) females fed with Tenebrio molitor (Coleoptera: Tenebrionidae) pupae on plants of the insect-susceptible soybean 'UFVS-2006' (T1) or insectresistant 'IAC-24' (T2). 


\section{DISCUSSION}

The shortest duration of the IV instar of $P$. nigrispinus with insect-resistant 'IAC-24' did not reduce the duration of the nymph stage of this predator. However, the shortest duration of IV instar of P. maculiventris reduced the duration of the nymph stage of this predator with pupae of T. molitor (De Clercq et al., 1998). The xylem and parenchyma in the primary and secondary veins of the leaves are two of the feeding sites of predatory hemipterans on plants (Torres et al., 2010). Leaves of the resistant 'IAC-24' soybean showed signs of the insertion of the stylet bundle of $P$. nigrispinus and pupae of $T$. molitor were preyed, showing that this insect feeds on both food types.

The absence of direct deleterious effects of the resistant 'IAC-24' soybean on P. nigrispinus nymphs allows this predator to reach the adult stage and to reproduce more quickly and with a higher number of generations per soybean cultivation crop. This differs from the longer duration of the nymph stage of males and females of this predator with the resistant 'IAC-17' soybean to insects compared to the susceptible 'UFV-16' by direct effect (Matos Neto et al., 2002), indicating a different degree of resistance between the 'IAC-24' and 'IAC-17'. These cultivars have, in their genealogy, the lineage ' $\mathrm{D} 72$ 9601-1', selected for resistance to Pseudoplusia includens Walker, 1857 (Lepidoptera: Noctuidae) in the USA. This lineage descended from the 'PI 229358' lineage, which is a genotype with multiple resistances to insects (Miranda et al., 2003). Cultivar 'IAC-24' also has this resistant 'PI 227687' lineage, constituting an additional source of genetic variability and a broader genetic base for resistance to insects and biotic factors. 'IAC-24' and 'IAC-17' had similar levels of antibiosis-type resistance to A. gemmatalis (Fugi et al., 2005). Phytophagy on the insect-resistant soybean genotype 'PI 229358' also increased the duration of nymph stage of females of the predator Nabis roseipennis Reuter, 1872 (Hemiptera: Nabidae) (Pfannenstiel and Yeargan, 1998).

The higher survival rate of P. nigrispinus in the III instar on insect-resistant 'IAC-24' plants differs from the reduction of this parameter for the predator Geocoris punctipes Say, 1832 (Hemiptera: Lygaeidae) with the insect-resistant soybeans 'PI171451' and 'PI229358' (Rogers and Sullivan, 1986), but the latter did not affect the survival of the predator N. roseipennis (Pfannenstiel and Yeargan, 1998). The soybean 'IAC-24' can supplement nutrients for $P$. nigrispinus, as reported for the survival of adults of Brontocoris tabidus Signoret, 1852 (Heteroptera: Pentatomidae) with leaves of Eucalyptus spp. (Myrtaceae) and pupae of T. molitor, suggesting that the combination of prey and plants can improve breeding predatory insects in laboratory (Zanuncio et al., 2000). Plant quality is important, because survival of $B$. tabidus nymphs was higher with Gossypium hirsutum L.
(Malvaceae) than with Phaseolus vulgaris L. (Fabaceae) and similar with Amaranthus lividus L. (Amaranthaceae) (Coelho et al., 2009).

The similar body mass of males and females $P$. nigrispinus, during the III, IV, and $\mathrm{V}$ instars showed that 'IAC-24' may not have deleterious effects on the reproductive capacity of this predator. However, the weight of male and female $N$. roseipennis was lower with larvae of $P$. includens and the insect-resistant soybean 'PI229358' (Pfannenstiel and Yeargan, 1998). This is in accordance with the lower weight of female P. nigrispinus in the resistant 'IAC-17' soybean (Matos Neto et al., 2002), showing that the resistant plant and natural enemies must be analyzed separately. The weight of 15-d-old female B. tabidus was higher with pupae of T. molitor on plants of Eucalyptus cloeziana F. Muell., Eucalyptus urophylla S.T. Blake or Psidium guajava L. (Myrtaceae) than only with pupae of this prey. Females of 21-d-old of this predator presented higher weight with plants of E. cloeziana or P. guajava compared to $E$. urophylla and pupae of T. molitor or only pupae of this prey, although the protein content in the hemolymph of females of this predator was similar between treatments (Lemos et al., 2009). Heavier predatory females are important because there is a direct relationship in $P$. nigrispinus, Supputius cincticeps Stål, 1860 and Podisus rostralis Stål, 1860 (Heteroptera: Pentatomidae) between weight and fecundity (Mohaghegh et al., 1999; Zanuncio et al., 2002). Furthermore, adults with heavier body mass have better chances to survive in periods of prey scarcity (Molina-Rugama et al., 1998).

The similar pre-oviposition period of $P$. nigrispinus females with the resistant 'IAC-24' soybean agrees to that for this predator with soybeans 'IAC-17' and 'UFV16', resistant and susceptible to insects respectively, without deleterious effect (Matos Neto et al., 2002) and the lack of effect of the soybean 'PI227687' resistant to insects on the pre-oviposition period of $P$. maculiventris (Orr and Boethel, 1986). A shorter pre-oviposition period may avoid reduction of population growth of this predator.

The lack of impact of the soybean 'IAC-24' resistant to insects in the oviposition period of $P$. nigrispinus differs from the deleterious effect of resistant 'IAC-17' for this predator, indicating variations in levels of resistance between cultivars (Matos Neto et al., 2002). Simultaneous comparison of these cultivars in the field is not possible since they have different maturity cycles. Therefore, experiments have been separately made. 'IAC-24' is also resistant to the whitefly Bemisia tabaci Gennadius biotype B (Hemiptera: Aleyrodidae) because of which it was recommended for cultivation in regions and/or periods with problems or with cultures susceptible to this whitefly and cultivated simultaneously or in sequence with this crop (Valle et al., 2012). 
The lowest post-oviposition values of P. nigrispinus with the insect-resistant soybean 'IAC-17' (Matos Neto et al., 2002) indicate that females live only briefly after their last egg mass, which reduced the possibility of lower population growth of this predator. Short post-oviposition and longer oviposition periods of $P$. nigrispinus are desirable in biological control programs to reduce multiplication costs. Nevertheless, nymphs of predatory insects with low nutritional prey produce adults with low fertility (Wittmeyer et al., 2001) compared to one with prey of better quality or different types (Zanuncio et al., 2001).

The same interval between egg-laying and egg incubation of $P$. nigrispinus with 'IAC-24' to those with 'IAC-17' (Matos Neto et al., 2002) indicates the compatibility of resistant soybean plants with the biological control of this predator.

The similar numbers of egg masses and eggs per egg masses per $P$. nigrispinus female shows the compatibility of insect-resistant 'IAC-24' with the reproduction of this predator, and differs from the deleterious effect of resistant 'IAC-17' on the number of egg mass and eggs per egg masses per female of this predator (Matos Neto et al., 2002). Females of $B$. tabidus laid an average of 4.2 eggs per day and a total of 601.1 eggs with prey and leaves of Eucalyptus spp., suggesting that this plant is an adequate substrate for oviposition of this insect (Zanuncio et al., 2006). The higher number of eggs and nymphs of B. tabidus with A. lividus, G. hirsutum, or P. vulgaris and prey than only with these plants can improve its reproduction (Coelho et al., 2009).

The similar number of eggs per P. nigrispinus female shows the compatibility of 'IAC-24' to this predator as observed with 'IAC-17' (Matos Neto et al., 2002) and of P. maculiventris with insect-resistant 'PI227687' (Orr and Boethel, 1986). The number of eggs per female (357.79 at 554.00) of P. nigrispinus was higher with caterpillars of A. gemmatalis and soybean leaflets (Matos Neto et al., 2002) and plant material with prey increased the fecundity of B. tabidus (Zanuncio et al., 2000) and of P. nigrispinus (Lemos et al., 2001; Freitas et al., 2006). Predatory insects can use plants as supplementary food to increase their sustainability in prey-scarce habitats (Coll and Guershon, 2002; Zanuncio et al., 2004; Lemos et al., 2009).

The numbers of eggs and nymphs per $P$. nigrispinus female with the insect-resistant soybean 'IAC-24' resistant and the insect-susceptible 'UFV-2006' are similar to those for the resistant 'IAC-17' (Matos Neto et al., 2002). On the other hand, the reproductive capacity of $S$. cincticeps was lower when exposed to permethrin, indicating the deterring effect of this insecticide and that it may be harmful to this insect (Zanuncio et al., 2005). Macrolophus melanotoma Costa, 1853 (Hemiptera: Miridae) laid 69.55 eggs per female with leaves of Dittrichia viscosa L. (W. Greuter) (Asteraceae) or this plant with Capitophorus inulae Passerini, 1860 (Hemiptera: Aphididae) and only 10.80 eggs with leaves of this plant, showing the need for prey (Perdifeis et al., 2007). The number of eggs per B. tabidus female was also higher with prey and plants of A. lividus or G. hirsutum than with $P$. vulgaris, showing different results with this association for predatory insects (Coelho et al., 2009).

The similar life span of $P$. nigrispinus females is in accordance with that for this predator on 'IAC-17' (Matos Neto et al., 2002) and for P. maculiventris with 'PI 227687' (Orr and Boethel, 1986), both resistant to insects. The compatibility of insect-resistant 'IAC-24' with longer life span and lower initial mortality of $P$. nigrispinus females with this cultivar was similar to that for this predator with IAC-17 (Matos Neto et al., 2002). The longer life span and higher number of nymphs per female of B.tabidus with prey and plants of A.lividus or $G$. hirsutum and lower with those of $P$. vulgaris suggests the effect of plant type on these parameters (Coelho et al., 2009).

\section{CONCLUSIONS}

The insect-resistant soybean 'IAC-24' presented no direct deleterious effects on the majority of characteristics of $P$. nigrispinus, except in the duration of the IV instar and survival of the III instar, which implies its innocuousness and compatibility with this predator.

\section{ACKNOWLEDGEMENTS}

The authors thank MSc. Manuel A. Solís Vargas (Costa Rica) and MSc. Manuel Alejandro Ix Balam (Mexico) for the Spanish abstract. They are also grateful to 'Conselho Nacional de Desenvolvimento Científico e Tecnológico (CNPq)', 'Coordenação de Aperfeiçoamento de Pessoal de Nível Superior (CAPES)' and 'Fundação de Amparo à Pesquisa do Estado de Minas Gerais (FAPEMIG)' for financial support, and to Group Solucion of Brazil for translating this manuscript to English.

Efectos no directos de resistencia del cultivar de soya IAC-24 sobre Podisus nigrispinus (Heteroptera: Pentatomidae). Los parámetros de supervivencia, desarrollo y reproducción de Podisus nigrispinus Dallas, 1851 (Heteroptera: Pentatomidae) pueden verse afectados por la alimentación en cultivos de soya (Glycine max [L.] Merr.; Fabaceae). Se evaluó el efecto directo de la soya 'IAC-24' resistente a insectos (soya 'UFVS-2006' susceptible a insectos + pupas de Tenebrio molitor L., 1758 [Coleoptera: Tenebrionidae] vs. plantas 'IAC-24' + pupas de T. molitor) sobre los estados de ninfa y adulto del depredador P. nigrispinus. La duración del estado ninfal fue similar entre tratamientos, no obstante 'IAC24 ' redujo la duración del IV estado de este depredador. La supervivencia de $P$. nigrispinus fue similar entre los 
tratamientos en los estados I, II, IV y V y en el estado de ninfa, la supervivencia del estado III fue mayor con las plantas 'IAC-24'. La masa corporal de las ninfas en el primer día, en los estados III, IV, y V después de la ecdisis y adultos recién emergidos; características reproductivas (períodos de pre-oviposición, oviposición, post-oviposición e incubación de los huevos; intervalo de colocación de los huevos, número de masa de huevos por hembra, ninfas por hembra, ninfas por masa de huevos y porcentaje de eclosión de ninfas) y vida útil de machos y hembras de $P$. nigrispinus fueron similares entre los tratamientos. La soya resistente 'IAC-24' no mostró efectos nocivos directos en $P$. nigrispinus, lo que implica su inocuidad y compatibilidad con este depredador.

Palabras clave: Asopinae, control biológico, depredadores, manejo integrado de plagas, soya.

\section{LITERATURE CITED}

Bartlett, R. 2008. Negative interactions between chemical resistance and predators affect fitness in soybeans. Ecological Entomology 33:673-678.

Coelho, R.R., A.F.S.L. Veiga, and J.B. Torres. 2009. Feeding preference and performance of Brontocoris tabidus (Signoret) (Hemiptera, Pentatomidae) among host plants. Revista Brasileira de Entomologia 53:475-481

Coll, M., and M. Guershon. 2002. Omnivory in terrestrial arthropods: mixing plant and prey diets. Annual Review of Entomology 47:267-297.

Corrêa-Ferreira, B.S. 2005. Susceptibility of soybean stink bugs prior to pod development. Pesquisa Agropecuária Brasileira 40:1067-1072.

De Clercq, P., F. Merlevede, and L. Tirry. 1998. Unnatural prey and artificial diets for rearing Podisus maculiventris (Heteroptera: Pentatomidae). Biological Control 12:137-142.

Ferreira, J.A.M., J.C. Zanuncio, J.B. Torres, and A.J. MolinaRugama. 2008. Predatory behaviour of Podisus nigrispinus (Heteroptera: Pentatomidae) on different densities of Anticarsia gemmatalis (Lepidoptera: Noctuidae) larvae. Biocontrol Science and Technology 18:711-719.

Freitas, S.P.C., W.S. Evangelista Júnior, J.C. Zanuncio, and J.E. Serrão. 2006. Development, survival and reproduction of Podisus nigrispinus (Dallas, 1851) (Heteroptera: Pentatomidae) with salt and amino acids solutions supplementary diet. Brazilian Archives of Biology and Technology 49:449-455.

Fugi, C.G.Q., A.L. Lourenção, and J.R.P. Parra. 2005. Biology of Anticarsia gemmatalis on soybean genotypes with different degrees of resistance to insects. Scientia Agricola 62:31-35.

Kartohardjono, A., and E.A. Heinrichs. 1984. Populations of the brown planthopper, Nilaparvata lugens (Stal) (Homoptera: Delphacidae), and its predators on rice varieties with different levels of resistance. Environmental Entomology 13:359-365.

Lemos, W.P., R.S. Medeiros, F.S. Ramalho, and J.C. Zanuncio. 2001. Effects of plant feeding on the development, survival and reproduction of Podisus nigrispinus (Dallas) (Heteroptera: Pentatomidae). International Journal of Pest Management 47:8993.

Lemos, W.P., J.E. Serrão, J.C. Zanuncio, M.C. Lacerda, T.V. Zanuncio, and R.C. Ribeiro. 2009. Body weight and protein content in the haemolymph of females of the zoophytophagous predator Brontocoris tabidus (Heteroptera: Pentatomidae) with different diets and ages. Journal of Plant Diseases and Protection 116:218-222.
Matos Neto, F.C., J.C. Zanuncio, M.C. Picanço, and I. Cruz. 2002. Reproductive characteristics of the predator Podisus nigrispinus fed with an insect resistant soybean variety. Pesquisa Agropecuária Brasileira 37:917-924.

Miranda, M.A.C., N.R. Braga, A.L. Lourenção, F.T.S. Miranda, S.H. Unêda, and M.F. Ito. 2003. Description, yield and stability of early soybean insect resistant cultivar IAC-24. Bragantia 62:29-37.

Mohaghegh, J., P. De Clercq, and L. Tirry. 1999. Effects of rearing history and geographical origin on reproduction and body size of the predator Podisus nigrispinus (Heteroptera: Pentatomidae). European Journal of Entomology 96:69-72.

Molina-Rugama, A.J., J.C. Zanuncio, T.V. Zanuncio, and M.L.R. Oliveira. 1998. Reproductive strategy of Podisus rostralis (Stal) (Heteroptera: Pentatomidae) females under different feeding intervals. Biocontrol Science and Technology 8:583-588.

Neves, R.C.D., J.B. Torres, and J.C. Zanuncio. 2010. Production and storage of mealworm beetle as prey for predatory stinkbug. Biocontrol Science and Technology 20:1013-1025.

Orr, D.B., and D.J. Boethel. 1986. Influence of plant antibiosis through four trophic levels. Oecologia 70:242-249.

Perdifeis, D., C. Fauas, D. Lykouressis, and A. Fantinou. 2007. Ecological relationships between non-cultivated plants and insect predators in agroecosystems: the case of Dittrichia viscosa (Asteraceae) and Macrolophus melanotoma (Hemiptera: Miridae). Acta Oecologica 31:299-306.

Pfannenstiel, R.S., and K.V. Yeargan. 1998. Partitioning two- and three-trophic-level effects of resistant plants on the predator, Nabis roseipennis. Entomologia Experimentalis et Applicata 88:203-209.

Piubelli, G.C., F. Moscardi, and C.B. Hoffmann-Campo. 2009. Interactions among insect-resistant soybean genotypes extracts with populations of Anticarsia gemmatalis Hübner (Lepidoptera: Noctuidae) susceptible and resistant to its nucleopolyhedrovirus. Anais da Academia Brasileira de Ciências 81:861-871.

Rogers, D.J., and M.J. Sullivan. 1986. Nymphal performance of Geocoris punctipes (Hemiptera: Lygaeidae) on pest-resistant soybeans. Environmental Entomology 15:1032-1036.

Saavedra, J.L.D., J.C. Zanuncio, T.V. Zanuncio, and R.N.C. Guedes. 1997. Prey capture ability of Podisus nigrispinus (Dallas) (Het, Pentatomidae) reared for successive generations on a meridic diet. Journal of Applied Entomology 121:327-330.

SAS Institute. 1989. SAS/STAT user's guide. Version $6.4^{\text {th }}$ ed. 846 p. SAS Institute, Cary, North Carolina, USA.

Tavares, W.S., I. Cruz, F. Petacci, S.L. Assis Júnior, S.S. Freitas, J.C. Zanuncio, and J.E. Serrão. 2009. Potential use of Asteraceae extracts to control Spodoptera frugiperda (Lepidoptera: Noctuidae) and selectivity to their parasitoids Trichogramma pretiosum (Hymenoptera: Trichogrammatidae) and Telenomus remus (Hymenoptera: Scelionidae). Industrial Crops and Products 30:384-388.

Tavares, W.S., C. Hansson, J.E. Serrão, and J.C. Zanuncio. 2011. First report of Trichospilus pupivorus (Hymenoptera: Eulophidae) parasitizing pupae of Anticarsia gemmatalis (Lepidoptera: Noctuidae). Entomologia Generalis 33:281-282.

Torres, J.B., E.M. Barros, R.R. Coelho, and R.M.M. Pimentel. 2010. Zoophytophagous pentatomids feeding on plants and implications for biological control. Arthropod-Plant Interactions 4:219-227.

Valle, G.E., A.L. Lourenção, and J.B. Pinheiro. 2012. Adult attractiveness and oviposition preference of Bemisia tabaci biotype B in soybean genotypes with different trichome density. Journal of Pest Science 85:431-442.

Wittmeyer, J.L., T.A. Coudron, and T.S. Adams. 2001. Ovarian development, fertility and fecundity in Podisus maculiventris (Say) (Heteroptera: Pentatomidae): an analysis of the impact of nymphal, adult, male and female nutritional source on reproduction. Invertebrate Reproduction and Development 39:920 . 
Zanuncio, J.C., M.C. Lacerda, J.S. Zanuncio Júnior, T.V. Zanuncio, A.M.C. Silva, and M.C. Espindula. 2004. Fertility table and rate of population growth of the predator Supputius cincticeps (Heteroptera: Pentatomidae) on one plant of Eucalyptus cloeziana in the field. Annals of Applied Biology 144:357-361.

Zanuncio, J.C., W.P. Lemos, M.C. Lacerda, T.V. Zanuncio, J.E. Serrão, and E. Bauce. 2006. Age-dependent fecundity and fertility life tables of the predator Brontocoris tabidus (Heteroptera: Pentatomidae) under field conditions. Journal of Economic Entomology 99:401-407.

Zanuncio, J.C., A.J. Molina-Rugama, G.P. Santos, and F.S. Ramalho. 2002. Effect of body weight on fecundity and longevity of the stinkbug predator Podisus rostralis. Pesquisa Agropecuária Brasileira 37:1225-1230.
Zanuncio, J.C., A.J. Molina-Rugama, J.E. Serrão, and D. Pratissoli. 2001. Nymphal development and reproduction of Podisus nigrispinus (Heteroptera: Pentatomidae) fed with combinations of Tenebrio molitor (Coleoptera: Tenebrionidae) pupae and Musca domestica (Diptera: Muscidae) larvae. Biocontrol Science and Technology 11:331-337.

Zanuncio, J.C., T.V. Zanuncio, R.N.C. Guedes, and F.S. Ramalho. 2000. Effect of feeding on three Eucalyptus species on the development of Brontocoris tabidus (Het.: Pentatomidae) fed with Tenebrio molitor (Col.: Tenebrionidae). Biocontrol Science and Technology 10:443-450.

Zanuncio, T.V., J.C. Zanuncio, J.E. Serrão, R.S. Medeiros, T.B.M. Pinon, and C.A.Z. Sediyama. 2005. Fertility and life expectancy of the predator Supputius cincticeps (Heteroptera: Pentatomidae) exposed to sublethal doses of permethrin. Biological Research $38: 31-39$ 